\title{
Assessment of Commuter Satisfaction in the Usage of Bus-Shelters: the Ataköy Zone 5 and Beşyol Metrobus Stops, Istanbul
}

\author{
Gökçen Firdevs Yücel Caymaz, Istanbul Aydin University, Istanbul, Turkey
}

\begin{abstract}
Bus shelters, which form a part of daily lives of people, generally provide service as small areas of urban space created for short-term periods of waiting. From the perspective of spatial design, it is important that an environment of good quality is provided for users of bus-shelters. This study proposed hypotheses to research how the physical design of bus shelters (location-accessibility, anthropometric characteristics, roofing and walls, lighting, electronic information, seating, etc.) affected general satisfaction of their users. To establish users' general satisfaction, direct observation was performed and the hypotheses were tested through surveys conducted at bus-shelters selected in two areas of Istanbul (Ataköy-Beşyol) with different economic levels, and an assessment was made of the users' satisfaction analyses and related problems of bus shelter design. In the conclusion, it was established that there is a significant correlation between general satisfaction and, among other things, the perceived degree of difficulty in getting on and off buses, the harmonization of bus shelter design with the surroundings, the adequacy of a shelter for summer use, the comfort of a shelter, the adequacy of seating, and the extent to which the shelter is maintained.
\end{abstract}

Keywords - Bus-shelter, bus-shelter design, user satisfaction, user perception.

\section{INTRODUCTION}

Before deciding what types of shelters are to be used in urban spaces, the need for a shelter, where it will be placed, how it will be designed, and maintenance procedures for it have to be determined. In the design of a bus-shelter, whatever the locality, it is essential to establish the connection of the bus-shelter to its physical environment and its relation to its users. It is important to ensure that there are clear and comfortable paths available to facilitate the movement of pedestrians around it, that shelters are at a distance from intersections, and that thought has been given to providing sufficient space for disabled users in wheelchairs. The purpose of this study is to identify the factors that determine bus-shelter users' satisfaction.

Bus shelters are necessary in locations where there are 10 or more passengers per hour [1]. In the choice of location, it is important to consider factors such as accessibility, traffic density, safety, sufficient space and the flow of passengers. Bus shelters must be located close to schools, shopping areas, libraries, homes for the elderly, hospitals and train stations, along traffic roads, and in places where they are easily visible to pedestrians, spaced at a distance of 400 to 800 metres (for the elderly and the disabled this distance is $100 \mathrm{~m}$ ) [2]-[4]. Shelters within city blocks can be set up in three different ways depending on whether they are on the near or far side of an intersection, or between intersec- tions [5]-[8]. Because pedestrian traffic is heavy at bus shelters near intersections, shelters have to be situated at least $3 \mathrm{~m}$ away from pedestrian crossings; and if a shelter is situated on the far side of an intersection, it should be at least $120 \mathrm{~m}$ away from the intersection in order to allow buses to stop there.

Safety, climate control, acoustic comfort, shelter from wind, visual comfort, accessibility, and harmonization with the surroundings are important criteria to be considered in designing bus shelters [9]-[11]. The kinds of design factors which may affect bus shelter design are shown in Fig. 1.

\section{Literature Review}

Although there are many studies related to bus stop planning [25], safety [26]-[29], and design [30]-[32], there are few studies on researching the relation between bus stop design and user satisfaction. Physical characteristics of the bus stop like bus shelter, seating equipment, signs, and lighting, etc. directly affect user satisfaction. Waiting time can be problematic for the users. Many people do not like waiting for bus long, like in the Kiaran et al. (2012) research results. Although most of the people interviewed waited for the bus for no longer than 10 minutes, they found the waiting time at the shelter too long. There are different age group users of the bus stop. Especially old age users have some special desires while using the stop area. The elderly found it more difficult to see the bus, as they preferred to wait sitting down. In another study, it was noted that for the elderly, the distance to the bus shelter, inadequate pedestrian walkways and inadequate bus shelter roofing constituted obstacles [33]. One of the conclusions of Woldeamanuel and Somers' 2016 study of 430 bus shelters in the Los Angeles area was that the comfort of use of people waiting at a bus shelter was affected negatively because the seating was inadequate and dirty [34]. Buys and Miller have established that shelters are more comfortable if the users do not have to wait standing up, and have a place near them where they can put any heavy possessions [35]. Pizzatoa et al., in their research in 2012, which focused on benches, surrounding vegetation and bus shelter roofing, concluded that female students were more likely to sit down than male students, and were more interested in the aesthetic aspects of the vegetation [36]. De Oliveira and Logsdon (2012) noted in their research, that although there was no sufficient information available inside a shelter regarding bus arrival times, $43 \%$ of the users said they got the information from the Internet [37]. Weather protection is another 


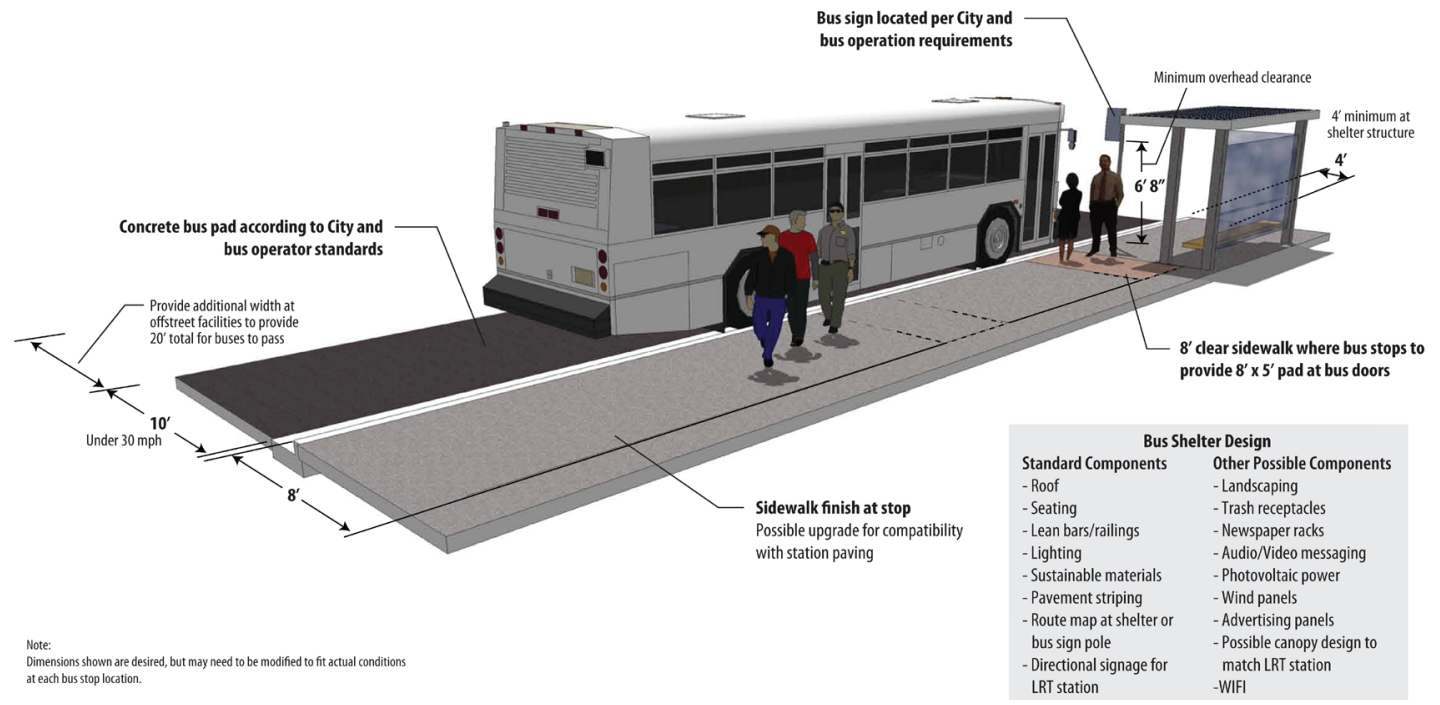

Fig. 1. Bus Shelter Design [12].

TABLE I

Criteria for Components of Shelter Design [Based on 2, 11, 13, 14, 15, 16, 17, 18, 19, 20]

\begin{tabular}{|c|c|}
\hline $\begin{array}{l}\text { Shelter design } \\
\text { components }\end{array}$ & Design priorities \\
\hline Dimensions & $\begin{array}{ll}\text { - } & \text { far side parallel to pedestrian pavement } \\
\text { - } & \text { minimum length } 3.1 \mathrm{~m} \\
\text { - } & \text { roofing of minimum width } 130 \mathrm{~cm} \mathrm{[13]}\end{array}$ \\
\hline Loading area & $\begin{array}{ll}\text { - } & \text { disabled-friendly ease of use } \\
\text { - } & \text { minimum width } 1.5 \mathrm{~m} \text {, depth } 2.4 \mathrm{~m} \text { (Fig. } 1) \\
\text { - } & \text { slip-resistant materials [14] }\end{array}$ \\
\hline Side Panels & $\begin{array}{ll}- & \text { transparent material } \\
- & \text { at least } 90 \mathrm{~cm} \text { in width } \\
\text { - } & \text { raised at a height of } 7 \mathrm{~cm} \text { from the floor to prevent trash from getting into the shelter and keep out draughts }\end{array}$ \\
\hline Roof & $\begin{array}{ll}\text { - } & \text { alternative materials which are transparent enough to permit light but not heat } \\
\text { - } & \text { protection from rain by an outer covering at a } 20^{\circ} \text { angle [11] } \\
\text { - } & \text { the shelter should be illuminated using photovoltaic cells (Transfort, 2015) (Fig. 2) }\end{array}$ \\
\hline Waiting area & $\begin{array}{ll}- & \text { sufficient width } \\
- & \text { flooring of durable, non-slip material [14] }\end{array}$ \\
\hline Seating Area & $\begin{array}{ll}\text { - } & \text { comfortably arranged with a view of the street [15] (Fig. } 3 \text { ) } \\
\text { - } & \text { width } 2 \mathrm{~m} \text {, height from the floor } 450-550 \mathrm{~mm} \text {, depth } 400-500 \mathrm{~mm} \text {, armrest height } 180-250 \mathrm{~mm} \\
\text { - } & \text { set in } 600 \mathrm{~mm} \text { from the road } \\
\text { - } & \text { railings } 80 \mathrm{~cm} \text { high [2], [14], [16] }\end{array}$ \\
\hline Trash cans & $\begin{array}{ll}- & \text { sufficient in number } \\
\text { - } & \text { emptied regularly } \\
\text { - } & \text { presentable visual quality [13], [17] }\end{array}$ \\
\hline Signage & 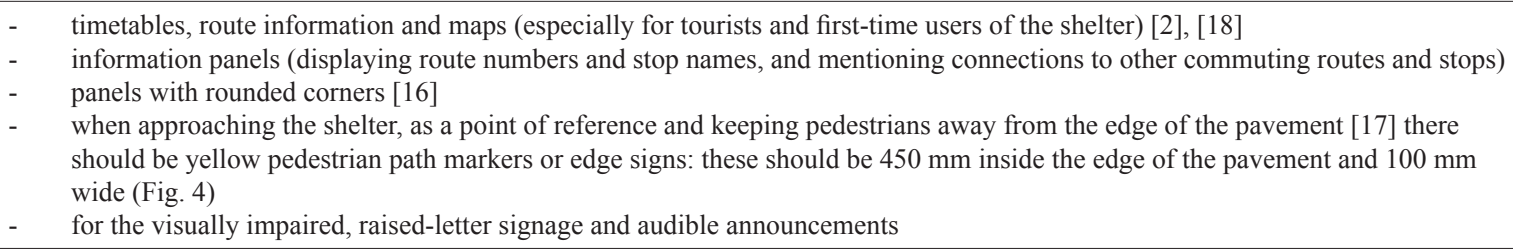 \\
\hline Lighting & $\begin{array}{ll}\text { - } & \text { provided by a nearby streetlight, installed within the shelter, or a stand-alone light pole [19] } \\
\text { - } & \text { illumination of the waiting area and notice-boards } \\
\text { - } & \text { use of white light } \\
- & \text { ceiling-reflecting lighting directed upwards (Fig. 5) } \\
- & \text { lighting of, on average, } 1.3-2.6 \text { foot-candles or 13-26 lux (Table II) } \\
\text { - } & \text { advertising panels should be illuminated using energy-efficient lamps and fittings sensitive to solar energy and daylight } \\
\text { (Table III) [20] }\end{array}$ \\
\hline
\end{tabular}



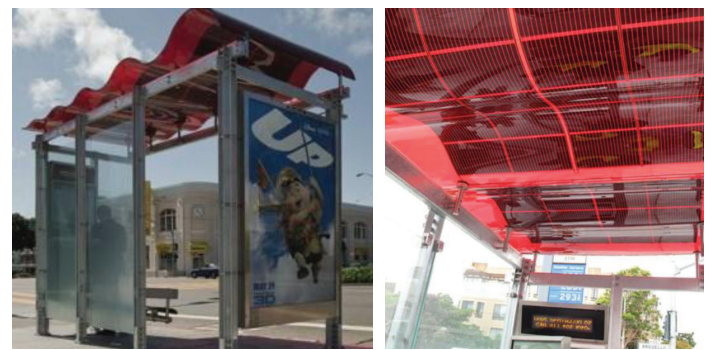

Fig. 2. Solar-powered bus shelter and a detail of roof, San Francisco, Photograph: Matthew Roth [21].
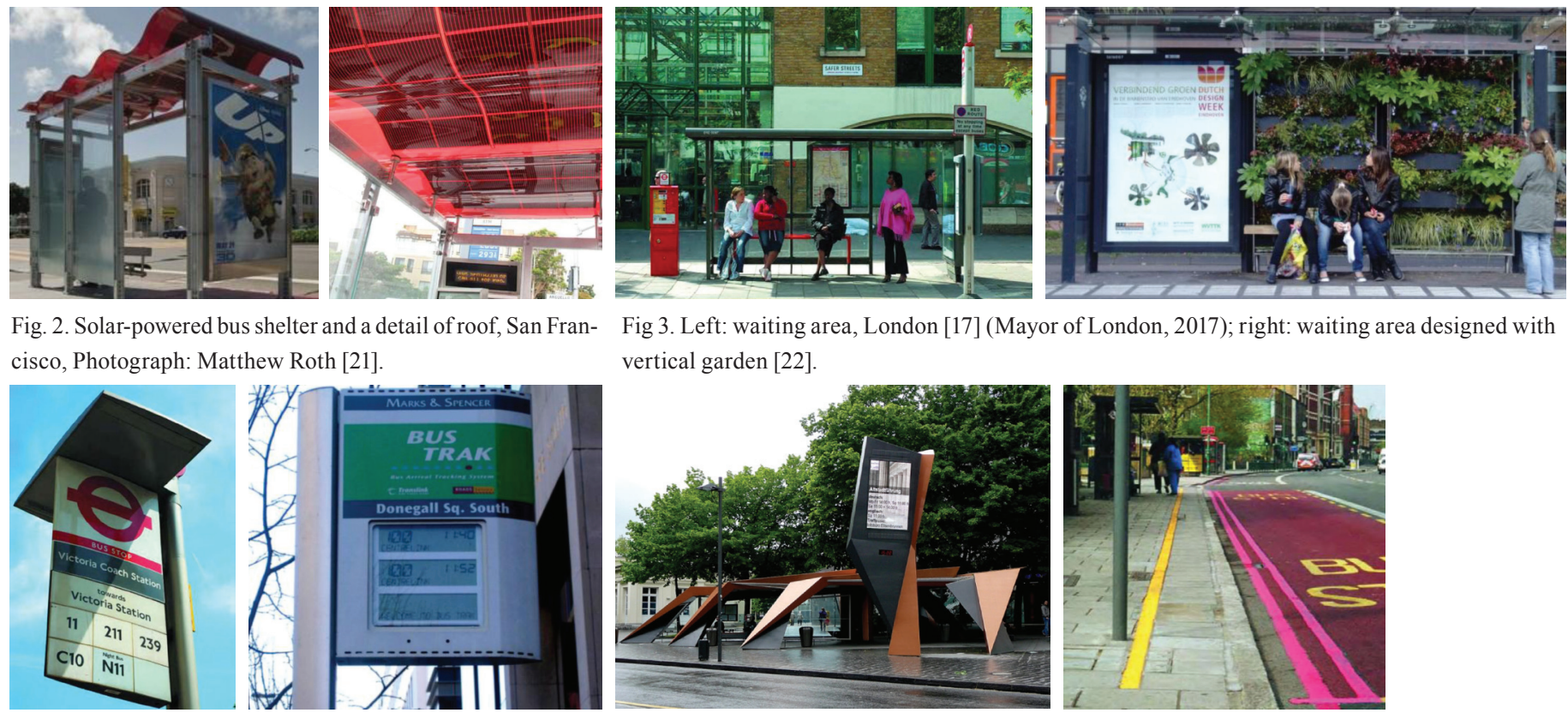

Fig 3. Left: waiting area, London [17] (Mayor of London, 2017); right: waiting area designed with vertical garden [22].
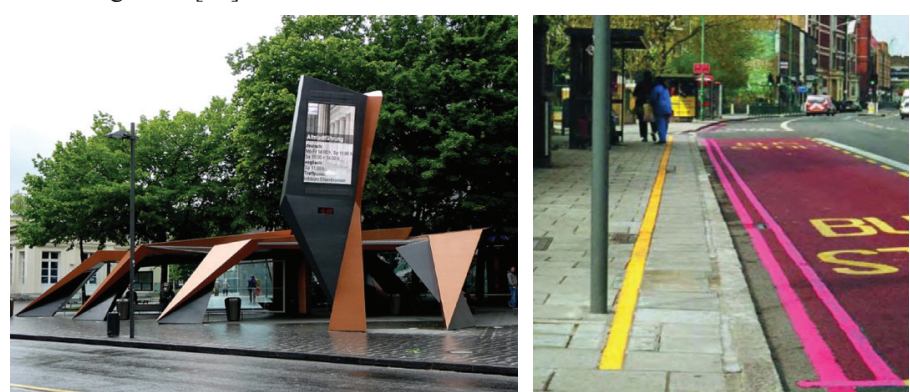

Fig. 4. Left: Bus-stop signpost illuminated by solar cells [17]; middle left: electronic travelers' information screen [2]; middle right: a clock with an electronic information screen, Peter Eisenman's Bus Shelter in Aachen Germany [23]; right: yellow pedestrian guide lines, London [17].

TABLE II

Lighting Levels of Advertising Panels in Bus Shelters [24]

\begin{tabular}{|c|c|}
\hline Illuminated area $\left(\mathbf{m}^{\mathbf{2}}\right)$ & Illumination level (cd) \\
\hline up to 0.5 & 1000 \\
\hline $0.5-2.0$ & 800 \\
\hline $2.0-10.0$ & 600 \\
\hline
\end{tabular}

important issue, especially in winter. According to a study at Florianópolis in Brazil conducted by Elya et al., $62 \%$ of users thought their shelter roof coverings were too small, $83 \%$ found the weather protection inadequate, and $70 \%$ thought the shelter was too hot in summer. People feel more comfortable when they are safe in the bus stop. Nabors et al. emphasize that taking into account the safety of a shelter should be a priority before considering improving the other design criteria, because if shelters are not safe enough, in time, people will no longer want to use them [38]. Nikolopoulou et al., and also Saravia and Pinho, state that it is important to establish a safer environment through natural surveillance, and that it is essential for the shelter to be easily visible from surrounding areas, and to have adequate lighting and maintenance [39], [40]. Iseki et al. (2007) found that, while users of a shelter considered important such factors as the safety of the shelter at night, buses running on time, the availability of assistance in case of emergencies, good lighting at night, and not having to wait too long, they attached less importance to other matters, such as finding the timetable at the shelter, the cleanliness of the shelter, or the availability of seating [41].

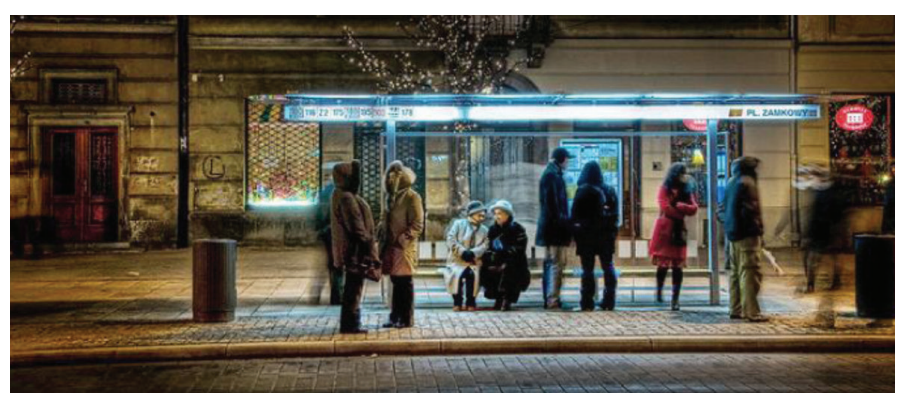

Fig. 5. Bus shelter lighting. Photograph: Bartek Kuzia [11].

\section{Materials and Methods}

\section{A. Research Method and Sampling}

Two areas with different socio-demographic characteristics (the Ataköy-Beşyol districts) within the provincial borders of Istanbul were selected for the purpose of determining the level of satisfaction of bus passengers with their bus shelters (Figs. 6 and 7). Because the Ataköy Zone 5 stop is located in a residential area with a high socio-economic level, the Beşyol stop was chosen to represent a location in an area with a lower socio-economic level. The survey was conducted by randomly questioning passengers at the two different stops. The data was obtained from face-to-face questioning of 200 individuals. The questionnaire was divided into three parts: demographic factors of commuters, questions regarding shelter usage, and questions regarding the adequacy of the shelter design. Then ten hypothesis related with user satisfaction with the bus stop were determined and tested using the statistical program SPSS (Statistical Package for the Social Sciences). 

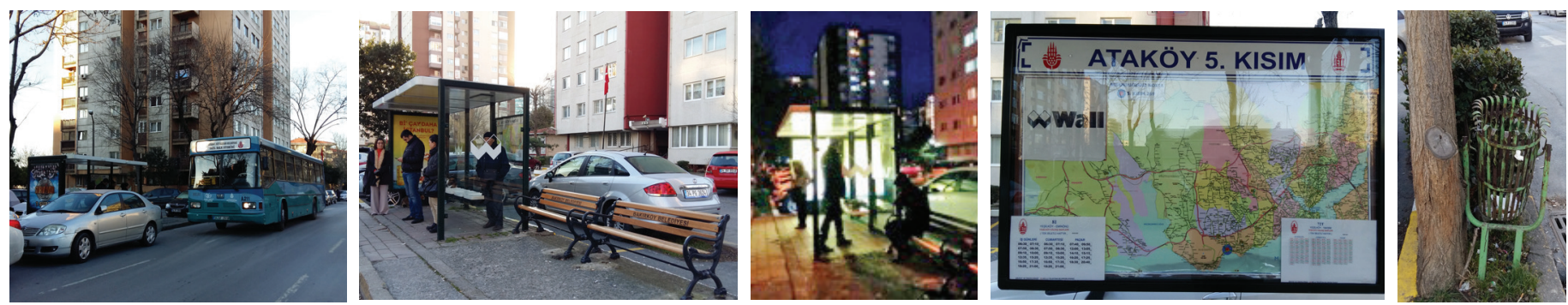

Fig. 6. Site of the Ataköy Zone 5 stop, General appearance of the shelters [Photos: Gökçen Firdevs Yücel Caymaz].
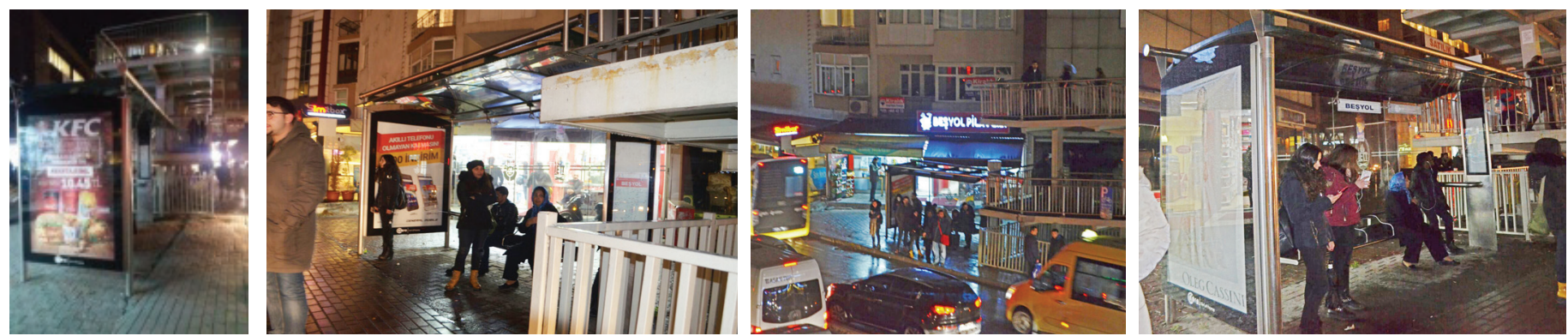

Fig. 7. Site of the Beşyol stop, General appearance of the shelters [Photos: Gökçen Firdevs Yücel Caymaz].

\section{B. Hypotheses}

H1: General satisfaction with the shelter varies according to whether the choice of location is found to be appropriate or not.

H2: General satisfaction with the shelter varies according to whether its adequacy for winter use is found to be satisfactory or not.

H3: General satisfaction with the shelter varies according to whether its adequacy for summer use is found to be satisfactory or not.

H4: General satisfaction with the shelter varies according to whether the shelter is found to be comfortable or not.

H5: General satisfaction with the shelter varies according to whether the seating at the shelter is found to be adequate or not.

H6: General satisfaction with the shelter varies according to whether the trash cans at the shelter are found to be sufficient or not.

H7: General satisfaction with the shelter varies according to whether the lighting is found to be adequate or not.

H8: General satisfaction with the shelter varies according to whether the signage is found to be adequate or not.

H9: General satisfaction with the shelter varies according to whether the shelter is perceived to be sufficiently safe or not.

H10: General satisfaction with the shelter varies according to whether the shelter is found to be well maintained or not.

\section{Users' Evaluation of Shelter Design}

\section{Demographic Factors of Commuters}

The relative proportions of male and female users were seen to be similar at both stops: at the Ataköy stop, $48 \%$ of the users were female and $52 \%$ male; while at the Beşyol stop, $51 \%$ were female and $49 \%$ male. In terms of marital status, there was a larger number of users who were single at the Beşyol stop: at the Ataköy stop, $47 \%$ of the users were single, and at the Beşyol stop, it was $64 \%$. Regarding age, the largest group of users at both stops was in the age group of $26-55$, who use the bus stop for going to school and work (Ataköy: $50 \%$, Beşyol: $41 \%$ ); while there were more users in the $56+$ age group at the Ataköy stop (Ataköy: $25 \%$, Beşyol: $9 \%$ ) because of more retired people in the Ataköy. The educational level of the largest number of users was tertiary and secondary at both stops (Ataköy: $59 \%$, $35 \%$; Beşyol: $60 \%$, $33 \%$ ). As regards income level, users of low-income groups were the majority at both stops (Ataköy: $63 \%$, Beşyol: $89 \%$ ). In terms of occupation, the majority of users of the Ataköy stop were engaged in paid employment (52\%), while at the Beşyol stop the user profile was more diverse: unemployed (28\%), paid employees (27\%), and students (23\%). A large proportion of the users at both stops had been residents in Istanbul for over 20 years (Ataköy: 66 \%, Beşyol: 48 \%). Finally, while the proportion of users of the Ataköy stop who were or were not vehicle owners were close (vehicle owners $41 \%$, non-owners $59 \%$ ), the proportion of users of the Beşyol stop who did not own a vehicle was quite high (90\%) (Table III). 
TABLE III

Socio-Demographic Analysis Of Users [Author of the Article]

\begin{tabular}{|c|c|c|}
\hline & Ataköy & Beşyol \\
\hline & Percentage (\%) & Percentage $(\%)$ \\
\hline $\begin{array}{l}\text { Sex } \\
\text { Female } \\
\text { Male }\end{array}$ & $\begin{array}{l}48 \\
52\end{array}$ & $\begin{array}{l}51 \\
49\end{array}$ \\
\hline $\begin{array}{l}\text { Marital status } \\
\text { Married } \\
\text { Single }\end{array}$ & $\begin{array}{l}53 \\
47\end{array}$ & $\begin{array}{l}36 \\
64\end{array}$ \\
\hline $\begin{array}{l}\text { Age group } \\
12-16 \\
17-25 \\
26-55 \\
56 \text { and over }\end{array}$ & $\begin{array}{l}1 \\
24 \\
50 \\
25\end{array}$ & $\begin{array}{l}0 \\
50 \\
41 \\
9\end{array}$ \\
\hline $\begin{array}{l}\text { Type of residence } \\
\text { Apartment } \\
\text { Public mass housing } \\
\text { Private house }\end{array}$ & $\begin{array}{l}98 \\
1 \\
1\end{array}$ & $\begin{array}{l}93 \\
4 \\
3\end{array}$ \\
\hline $\begin{array}{l}\text { Education level } \\
\text { Illiterate } \\
\text { Primary education } \\
\text { Secondary education } \\
\text { Tertiary Education }\end{array}$ & $\begin{array}{l}2 \\
4 \\
35 \\
59\end{array}$ & $\begin{array}{l}1 \\
6 \\
33 \\
60\end{array}$ \\
\hline $\begin{array}{l}\text { Monthly income } \\
\text { Low income } \\
\text { Average income } \\
\text { High income }\end{array}$ & $\begin{array}{l}63 \\
29 \\
8\end{array}$ & $\begin{array}{l}89 \\
10 \\
1\end{array}$ \\
\hline $\begin{array}{l}\text { Occupation } \\
\text { Paid employee } \\
\text { Free-lance } \\
\text { Unemployed } \\
\text { Housewife } \\
\text { Student } \\
\text { Retiree }\end{array}$ & $\begin{array}{l}52 \\
13 \\
11 \\
3 \\
11 \\
10\end{array}$ & $\begin{array}{l}27 \\
12 \\
28 \\
4 \\
23 \\
6\end{array}$ \\
\hline $\begin{array}{l}\text { Years of residency in } \\
\text { Istanbul } \\
1-5 \text { years } \\
6-20 \text { years } \\
\text { more than } 20 \text { years }\end{array}$ & $\begin{array}{l}9 \\
25 \\
66\end{array}$ & $\begin{array}{l}25 \\
27 \\
48\end{array}$ \\
\hline $\begin{array}{l}\text { Private vehicle owner } \\
\text { Yes } \\
\text { No }\end{array}$ & $\begin{array}{l}41 \\
59\end{array}$ & $\begin{array}{l}10 \\
90\end{array}$ \\
\hline
\end{tabular}

\section{Analysis of Questions Regarding Shelter Usage}

Most of the people use repeatidly both bus stops. At both shelters, a high proportion of users used the stops at least once a week (Ataköy: $46 \%$, Beşyol: $42 \%$ ), and daily (Ataköy: 35\%, Beşyol: $47 \%$ ). The results indicated that the Beşyol stop was heavily used for getting on and off buses ( $85 \%$ ), while the Ataköy stop was used for both buses and minibuses (Buses: $52 \%$, Minibuses: $47 \%$ ). Both shelters were heavily used on weekdays (Ataköy: $51 \%$, Beşyol: $57 \%$ ); the proportion using the stop on both weekdays and weekends was higher at the Ataköy stop (Ataköy: $40 \%$, Beşyol: $25 \%$ ). At both locations, users mostly waited for 6-20 minutes at the stop (Ataköy: $67 \%$, Beşyol: $70 \%$ ). For the majority of users of the Ataköy stop it took 0-5 minutes (79 \%) to get to the bus stop; while at Beşyol it varied from 6-20 minutes (41\%) to $0-5$ minutes $(34 \%)$. Similarly, while the proportion of users reaching the bus stop at Beşyol in 21 minutes or longer was $25 \%$, the proportion reporting taking such a time to reach the stop was only $3 \%$ at Ataköy (Table IV).

TABLE IV

Users' Evaluations Concerning the Use of Shelters [Author of the Article]

\begin{tabular}{|l|l|l|}
\hline & Ataköy & Beşyol \\
\hline & Percentage (\%) & Percentage (\%) \\
\hline Frequency of use & & \\
First time & $\mathbf{5}$ & \\
At least once a month & $\mathbf{1 4}$ & $\mathbf{6}$ \\
At least once a week & $\mathbf{4 6}$ & $\mathbf{5}$ \\
Every day & $\mathbf{3 5}$ & $\mathbf{4 2}$ \\
\hline Vehicles boarded at the stop & & $\mathbf{4 7}$ \\
Buses & $\mathbf{5 2}$ & \\
Buses and minibuses & $\mathbf{4 7}$ & $\mathbf{8 5}$ \\
Minibuses only & $\mathbf{1}$ & $\mathbf{9}$ \\
\hline Days the stop is used & & $\mathbf{6}$ \\
Weekends & $\mathbf{9}$ & \\
Weekdays & $\mathbf{5 1}$ & $\mathbf{1 8}$ \\
Both & $\mathbf{4 0}$ & $\mathbf{5 7}$ \\
\hline Waiting time & & $\mathbf{2 5}$ \\
0-5 min & $\mathbf{2 2}$ & $\mathbf{1 6}$ \\
6-20 min & $\mathbf{6 7}$ & $\mathbf{7 0}$ \\
21-30 min & $\mathbf{9}$ & $\mathbf{1 2}$ \\
30 min or longer & $\mathbf{2}$ & $\mathbf{2}$ \\
\hline Time to reach the bus stop & $\mathbf{7 9}$ & $\mathbf{4 1}$ \\
0-5 min & $\mathbf{1 8}$ & $\mathbf{1 0}$ \\
6-20 min & $\mathbf{3}$ & $\mathbf{0}$ \\
21-30 min & & \\
30 min or longer & & \\
\hline
\end{tabular}

\section{E. Questions Regarding the Adequacy of the Shelter Design}

At both stops, the users found the choice of location suitable (Ataköy: 98 \%, Beşyol: $95 \%$ ). The Ataköy stop has more comfortable and green environment than Beşyol. The Ataköy bus stop is in the residental area but Beşyol bus stop in both residential and commercial area. Thus, more people are using the Beşyol stop because of its location. The majority of users at the Ataköy stop indicated that it was easy to get on and off buses there $(79 \%)$, while at Beşyol, majority of users found it difficult (54\%). Majority of users of the Ataköy stop found the shelter design congruous with the environment (61\%). Majority of the users at Ataköy found the shelter adequate for winter use $(59.6 \%)$, while majority of users found the shelter at Beşyol inadequate for winter use (63.2\%). At both stops, the users found the shelter adequate for summer use (Ataköy: $80 \%$, Beşyol: $41 \%$ ). The proportion who found the comfort of the shelter inadequate was greater at Beşyol (Beşyol: 71 \%, Ataköy: 33 \%). Regarding seating facilities, the proportion who found them inadequate was greater at Beşyol (Beşyol: 80 \%, Ataköy: 43 \%); the proportion who found the seating adequate was greater at Ataköy (Ataköy: $39 \%$, Beşyol: $8 \%$ ). The proportion who found the trash cans inadequate was greater at the Beşyol stop (Beşyol: 83 \%, Ataköy: $37 \%$ ), as was the proportion who found the lighting inadequate 
(Beşyol: $63 \%$, Ataköy: $37.6 \%$ ). At both stops, users found the timetable inadequate (Ataköy: $96.9 \%$, Beşyol: $80.6 \%$ ). While users of the Ataköy stop found the shelter safe during the daytime (93\%), users of the Beşyol stop found the shelter unsafe or moderately safe (unsafe: $46 \%$, moderately safe: $21 \%$ ). A larger proportion found the safety inadequate at night at the Beşyol stop (Beşyol: $40 \%$, Ataköy: $15.5 \%$ ). The proportion of users who found the bus shelter well maintained was less at Beşyol than at Ataköy (Beşyol: $13 \%$, Ataköy: $24 \%$ ). Regarding general satisfaction with the shelters, a larger proportion at Beşyol reported low general satisfaction (Beşyol: $33 \%$, Ataköy: $11 \%$ ); while a smaller proportion at Ataköy reported high general satisfaction (Ataköy: $41 \%$, Beşyol: $16 \%$ ) (Table V).

$$
\text { TABLE V }
$$

Users' Evaluation of Bus-shelter [Author of the Article]

\begin{tabular}{|c|c|c|}
\hline & Ataköy & Beşyol \\
\hline & Percentage (\%) & $\begin{array}{l}\text { Percentage } \\
(\%)\end{array}$ \\
\hline $\begin{array}{l}\text { Need for the shelter } \\
\text { Unnecessary } \\
\text { Average } \\
\text { Necessary }\end{array}$ & $\begin{array}{l}2 \\
98\end{array}$ & $\begin{array}{l}1 \\
4 \\
95\end{array}$ \\
\hline $\begin{array}{l}\text { Choice of location } \\
\text { Unsuitable } \\
\text { Suitable }\end{array}$ & $\begin{array}{l}2 \\
98\end{array}$ & $\begin{array}{l}14 \\
86 \\
\end{array}$ \\
\hline $\begin{array}{l}\text { Ease of access to the bus } \\
\text { Difficult } \\
\text { Average } \\
\text { Easy }\end{array}$ & $\begin{array}{l}6 \\
45 \\
79\end{array}$ & $\begin{array}{l}54 \\
21 \\
25\end{array}$ \\
\hline $\begin{array}{l}\text { Harmony of design with } \\
\text { surroundings } \\
\text { Incongruous } \\
\text { Average } \\
\text { Congruous }\end{array}$ & $\begin{array}{l}18 \\
21 \\
61\end{array}$ & $\begin{array}{l}31 \\
35 \\
34\end{array}$ \\
\hline $\begin{array}{l}\text { Use of the shelter in winter? } \\
\text { Yes } \\
\text { No }\end{array}$ & $\begin{array}{l}94 \\
6\end{array}$ & $\begin{array}{l}87 \\
13 \\
\end{array}$ \\
\hline $\begin{array}{l}\text { Is the shelter adequate for use } \\
\text { winter? } \\
\text { Inadequate } \\
\text { Average } \\
\text { Adequate }\end{array}$ & $\begin{array}{l}21.3 \\
19.1 \\
59.6\end{array}$ & $\begin{array}{l}63.2 \\
9.2 \\
27.6\end{array}$ \\
\hline $\begin{array}{l}\text { Is the shelter adequate for use } \\
\text { summer? } \\
\text { Inadequate } \\
\text { Average } \\
\text { Adequate }\end{array}$ & $\begin{array}{l}5 \\
15 \\
80\end{array}$ & $\begin{array}{l}33 \\
26 \\
41\end{array}$ \\
\hline $\begin{array}{l}\text { Comfort of the shelter } \\
\text { Uncomfortable } \\
\text { Average } \\
\text { Comfortable }\end{array}$ & $\begin{array}{l}33 \\
41 \\
26\end{array}$ & $\begin{array}{l}71 \\
22 \\
7\end{array}$ \\
\hline $\begin{array}{l}\text { Adequacy of seating facilities } \\
\text { Inadequate } \\
\text { Average } \\
\text { Adequate }\end{array}$ & $\begin{array}{l}43 \\
18 \\
39\end{array}$ & $\begin{array}{l}80 \\
12 \\
8\end{array}$ \\
\hline
\end{tabular}

\begin{tabular}{|c|c|c|}
\hline $\begin{array}{l}\text { Adequacy of trash cans } \\
\text { Inadequate } \\
\text { Average } \\
\text { Adequate }\end{array}$ & $\begin{array}{l}37 \\
16 \\
47\end{array}$ & $\begin{array}{l}83 \\
9 \\
8\end{array}$ \\
\hline $\begin{array}{l}\text { Knowledge of lighting? } \\
\text { No } \\
\text { Yes }\end{array}$ & $\begin{array}{l}15 \\
85\end{array}$ & $\begin{array}{l}0 \\
100\end{array}$ \\
\hline $\begin{array}{l}\text { Adequacy of lighting } \\
\text { Inadequate } \\
\text { Average } \\
\text { Adequate }\end{array}$ & $\begin{array}{l}37.6 \\
28.2 \\
34.1\end{array}$ & $\begin{array}{l}63 \\
25 \\
12\end{array}$ \\
\hline $\begin{array}{l}\text { Knowledge of the bus schedule? } \\
\text { Yes } \\
\text { No }\end{array}$ & $\begin{array}{l}3 \\
97\end{array}$ & $\begin{array}{l}38 \\
62\end{array}$ \\
\hline $\begin{array}{l}\text { Adequacy of schedule } \\
\text { Inadequate } \\
\text { Average } \\
\text { Adequate }\end{array}$ & $\begin{array}{l}96.9 \\
1.0 \\
2.1\end{array}$ & $\begin{array}{l}80.6 \\
17.7 \\
1.6\end{array}$ \\
\hline $\begin{array}{l}\text { Daytime safety } \\
\text { Unsafe } \\
\text { Average } \\
\text { Safe }\end{array}$ & $\begin{array}{l}3 \\
4 \\
93\end{array}$ & $\begin{array}{l}46 \\
21 \\
33\end{array}$ \\
\hline $\begin{array}{l}\text { Knowledge of safety at night? } \\
\text { No } \\
\text { Yes }\end{array}$ & $\begin{array}{l}16 \\
84\end{array}$ & $\begin{array}{l}0 \\
100\end{array}$ \\
\hline $\begin{array}{l}\text { Safety at night } \\
\text { Unsafe } \\
\text { Average } \\
\text { Safe }\end{array}$ & $\begin{array}{l}15.5 \\
32.1 \\
52.4\end{array}$ & $\begin{array}{l}40 \\
17 \\
43\end{array}$ \\
\hline $\begin{array}{l}\text { Maintenance } \\
\text { Poorly maintained } \\
\text { Average } \\
\text { Well maintained }\end{array}$ & $\begin{array}{l}37 \\
39 \\
24\end{array}$ & $\begin{array}{l}45 \\
42 \\
13\end{array}$ \\
\hline $\begin{array}{l}\text { General satisfaction } \\
\text { Poor } \\
\text { Average } \\
\text { Good }\end{array}$ & $\begin{array}{l}11 \\
48 \\
41\end{array}$ & $\begin{array}{l}33 \\
51 \\
16\end{array}$ \\
\hline
\end{tabular}

\section{F. Testing of Hypotheses}

Based on the results of the $\mathrm{X}^{2}$ test, at the Ataköy Zone 5 stop, there was a significant correlation between general satisfaction and users' perceptions of the ease of getting on and off buses, the harmonization of the shelter design with the environment, the adequacy of the shelter for summer usage, the comfort of the shelter, the adequacy of seating, adequacy of trash cans, and how well the shelter is maintained. Based on the results of the $\mathrm{X}^{2}$ test, at the Beşyol stop, there was a significant correlation between general satisfaction and users' gender, as well as users' perceptions of the ease of getting on and off buses, the harmonization of the shelter design with the environment, the adequacy of the shelter for summer usage, its adequacy for winter usage, the comfort of the shelter, the adequacy of seating, adequacy of lighting, and how well the shelter is maintained (Table VI). 
TABLE VI

Results of Chi-Squared Analysis Between General Satisfaction and Use of the Stop [Author of the Article]

\begin{tabular}{|c|c|c|c|c|}
\hline & \multicolumn{4}{|c|}{ General Satisfaction } \\
\hline & \multicolumn{2}{|c|}{ Ataköy Zone 5 Stop } & \multicolumn{2}{|c|}{ Beşyol Stop } \\
\hline & Pearson chi-squared & Two-sided significance & $\begin{array}{l}\text { Pearson } \\
\text { chi-squared }\end{array}$ & Two-sided significance \\
\hline $\mathrm{H} 1$ & 2.211 & 0.331 & 3.204 & 0.201 \\
\hline $\mathrm{H} 2$ & 10.859 & $0.028 *$ & 19.723 & $0.001 *$ \\
\hline H3 & 31.637 & $0.000 *$ & 17.582 & $0.001 *$ \\
\hline $\mathrm{H} 4$ & 12.014 & 0.062 & 18.775 & $0.005^{*}$ \\
\hline H5 & 9.876 & $0.043^{*}$ & 12.061 & $0.017 *$ \\
\hline H6 & 26.498 & $0.000 *$ & 20.819 & $0.000 *$ \\
\hline $\mathrm{H} 7$ & 18.733 & $0.001 *$ & 23.189 & $0.000 *$ \\
\hline H8 & 20.740 & $0.000^{*}$ & 8.277 & 0.082 \\
\hline H9 & 12.476 & 0.052 & 18.511 & $0.001 *$ \\
\hline $\mathrm{H} 10$ & 40.064 & $0.000 *$ & 46.242 & $0.000 *$ \\
\hline
\end{tabular}

TABLE VII

Test Results for the Hypotheses [Author of the Article]

\begin{tabular}{|c|l|l|}
\hline Hypotheses & Ataköy Zone 5Stop & Beşyol Stop \\
\hline H1 & Rejected & Rejected \\
\hline H2 & Confirmed & Confirmed \\
\hline H3 & Confirmed & Confirmed \\
\hline H4 & Rejected & Confirmed \\
\hline H5 & Confirmed & Confirmed \\
\hline H6 & Confirmed & Confirmed \\
\hline H7 & Confirmed & Confirmed \\
\hline H8 & Confirmed & Rejected \\
\hline H9 & Rejected & Confirmed \\
\hline H10 & Confirmed & Confirmed \\
\hline * The difference is significant at a 0.05 significance level \\
\hline \multicolumn{2}{|l}{}
\end{tabular}

Hypotheses H2, H3, H5, H6, H7, and H10 were seen to be confirmed (Table VII).

\section{Conclusion}

Bus shelters play an essential role in fulfilling the needs of transportation planning. It is essential that they are designed and put in place properly, with care being taken to ensure the safety and security of pedestrians, cyclists, drivers and other road users. Designs that are to be implemented have to be carried out in accordance with international standards, and taking into consideration local usage needs and models. In all designs of open spaces, the general satisfaction of users is related to comfort of use, physical quality of the space, and the facilities made available to them. There are a large number of design parameters that vary acording to the specificities of the space and affect general satisfaction.Within the urban environment, bus shelters can be defined as small open spaces for short-term use. This study examined the extent to which different socio-demographic characteristics of users and the specific physical characteristics of bus shelters affected general satisfaction. As a result of the analyses it was established that differences in socio-demographic characteristics generally do not affect user satisfaction, with the exception that while a significant correlation was not found between gender and general satisfaction at the Ataköy stop, there was a significant correlation at the Beşyol stop. However, significant correlations were found between general satisfaction and users' perceptions of the ease of getting on and off buses, the harmonization of the shelter design with the environment, the adequacy of the shelter for winter and summer usage, the comfort of the shelter, the adequacy of seating, and how well the shelter is maintained. Although there are numerous studies on bus-shelter planning and the engineering and technology involved, there are only a few concerning such matters as their physical design. This study is intended to serve, among the others, as a resource in this field.

\section{REFERENCES}

1. King, R.D. Bus occupant safety. Transportation Research Board, 1996. $56 \mathrm{p}$

2. Road Service and Translink. Bus Stop Design Guide, Investor in People, 2005 [online, cited 22.05.2018]. http://www.planningni.gov.uk/downloads/ busstop-designguide.pdf

3. Johnson, V.D., Ponnuswamy, S. Urban transportation: planning, operation and management. Tata McGraw-Hill Education, 2012. $272 \mathrm{p}$.

4. Zeeger, Ch.V.Pedestrian facilities users guide: Providing safety and mobility. diane publishing, 2002. $162 \mathrm{p}$.

5. Imperial County Transportation Commission [online]. Bus Stop Design and Safety Guideline Handbook [cited 22.05.2018]. http://www.imperialctc.org/media/managed/news/Final-2014-ICTC-Bus-Stop-Design-andSafety-Guideline-Handbook.pdf, 2017

6. Voigt, N. R. Transportation Depth Reference Manual for the Civil PE Exam, Professional Publications Inc; 2nd Second Edition, 2016, 350 p.

7. Transfort [online]. Bus Stop Design Standards \& Guidelines [cited 22.05.2018]. http://www.ridetransfort.com/img/site_specific/uploads/Final_Design_Standards.pdf

8. Gattis, J. L. Guide for the geometric design of driveways. Transportation Research Board, 2010, 32 p. 
9. Grava, S. Urban transportation systems. Choices for communities. 2003 [online, cited 22.05.2018]. http://www.tfl.gov.uk/assets/downloads/businessandpartners/accessibile bus stop design guidance.pdf, 2004

10. Pecheux, K. K. Guidebook for mitigating fixed-route bus-and-pedestrian collisions. Transportation Research Board, 2008. 65 p.

11. Zhang, K. J. Bus Stop Urban Design: Nine Techniques for Enhancing Bus Stops and Neighbourhoods and their Application in Metro Vancouver B. Environment Design, Master Thesis, The University of British Columbia. 2012 .

12. Foothill Goldline [online]. Bus Stop Location and Design Criteria,Chap ter $3 \mid$ Proposed Bus/RAIL INTERFACE FACILITY IMPROVEMENTS, Foothill Extension Bus Interface Plan [cited 22.05.2018]. http://foothillgoldline.org/images/uploads/Chapter\%203 DRAFT.pdf.

13. GMPTE. Greater Manchester Passenger Transport Executive, Design Guidelines for Bus Stops in Greater Manchester, Manchester, 2007 [online, cited 22.05.2018]. http://chennaicityconnect.com/knowledgebase/ wp-content/uploads/2013/07/manchester-bus-design-guideline.pdf

14. Septa Bus Stop Design Guidelines. City of Philadelphia, Bucks County, Chester County, Delaware County, Montgomery County, 2012 [online, cited 22.05.2018]. https://septa.org/strategic-plan/reports/SEPTA-BusStop-Design-Guidelines-2012.pdf

15. Bus Stop Design \& Accessibility Guidelines, 2017. Memphis MPO Metropolitan Planning Organization [online, cited 22.05.2018]. http://memphismpo.org/sites/default/files/public/documents/transit-plans/bus-stop-design-and-accessbility-guidelines-apr-2017.pdf

16. BC Transit Municipal Systems Program, Design Guidelines for Accesible Bus Stops, 2013 [online]. Transit BC [cited 22.05.2018]. http://www.transitbc.com/corporate/resources/pdf/res-urban-21.pdf

17. London, Mayor Of. Accessible bus stop design guidance. 2006 [online, cited 22.05.2018]. http://content.tfl.gov.uk/accessibile-bus-stop-design-guidance.pdf

18. Tumlin, J. Sustainable transportation planning: Tools for creating vibrant healthy, and resilient communities. John Wiley \& Sons, 2012, 320 p.

19. Bus Stop Design Guide [online]. COTA (Central Ohıo Transit Authority) [cited 22.05.2018]. https://www.cota.com/wp-content/uploads/2016/04/ Bus-Stop-Design-Standards.pdf, 2014

20. Bus Shelter Policy, 2001 [online]. Holroyd City [cited 22.05.2018]. http:// www.holroyd.nsw.gov.au/PDFs/Your\%20Council/Policies/Roads\%20 and \%20Infrastucture/Bus\%20Shelter\%20Policy\%20.pdf

21. Tysons Corner Urban Design Guidelines, A Fairfax County, Virginia, 2012 [online]. Urban Design Guidelines Advisory Group [cited 22.05.2018]. publicationhttp://www.fairfaxcounty.gov/tysons/design/download/tysons udg.pdf

22. Groene bushokjes in Eindhoven, Oprukkend groen verbinden [online, cited 22.05.2018]. http://www.kaw.nl/project/groene-bushokjes-eindhoven/

23. Orange in roof and claw (Bus shelter by Peter Eisenman, Aachen, Germany) [online, cited 22.05.2018]. https://thebeautyoftransport. com/2014/04/02/orange-in-roof-and-claw-bus-shelter-by-peter-eisenmanaachen-germany/

24. Strategic Planning Services and Infrastructure Management Services. Transport Stops, Shelters and Seating [online]. The City of Newcastle [cited 22.05.2018]. https://www.newcastle.nsw.gov.au/getmedia/a2df7bc4-28a0 41d2-b836-110ad11d63c5/Transport stops shelters seating.aspx

25. Chien, S. I., Qin, Zh. Optimization of bus stop locations for improving transit accessibility. Transportation planning and Technology, 2004, Vol. 27, Issue 3, pp. 211-227. http://dx.doi.org/10.1080/0308106042000226899

26. Loukaitou-Sideris, A. Hot spots of bus stop crime: The importance of environmental attributes. Journal of the American Planning association, 1999, Vol. 65, Issue 4, pp. 395-411. https://doi.org/10.1080/01944369908976070

27. Hart, T. C., Miethe, T. D. Street robbery and public bus stops: a case study of activity nodes and situational risk. Security Journal, 2014, Vol. 27 Issue 2, pp. 180-193. https://doi.org/10.1057/sj.2014.5

28. Ibeas, A., et al. Optimizing bus stop spacing in urban areas. Transportation research part E: logistics and transportation review, 2010, Vol. 46 , Issue 3, pp. 446-458. http://dx.doi.org/10.3141/1731-03

29. Liggett, R., Loukaitou-Sideris, A., Iseki, H. Bus stop-environment connection: do characteristics of the built environment correlate with bus stop crime? Transportation Research Record: Journal of the Transportation Research Board, 2001, Vol. 1760, pp. 20-27. https://doi.org/10.3141/1760-03

30. Ewing, R. Using a visual preference survey in transit design. Public Works Management \& Policy, 2001, Vol. 5, Issue 4, pp. 270-280. https://doi. org/10.1177/1087724X0154002

31. Law, Ph., Taylor, B. Shelter from the storm: Optimizing distribution of bus stop shelters in Los Angeles. Transportation Research Record: Jour nal of the Transportation Research Board, 2001, Vol. 1753, pp. 79-85.

32. Fitzpatrick, K., et al. TCRP Report 19: Guidelines for the Location and Design of Bus Stops. Transportation Research Board of the National Academies, Washington, DC, 1996. 222 p. ISBN 0-309-06050-8 [online, cited 22.05.2018]. https://nacto.org/docs/usdg/tcrp report 19.pdf
33. Broome, K., et al. Evaluation of flexible route bus transport for older people. Transport Policy, 2012, Vol. 21, pp. 85-91. https://doi.org/10.1016/j.tranpol.2012.02.005

34. Woldeamanuel, M., Somers, A. When the Wait seems Longer: Assessing Quality Attributes of Bus Stops. TRB 95th Annual Meeting Compendium of Papers, 2016. 17 p. [online, cited 22.05.2018]. http://docs.trb.org/prp/160446.pdf

35. Buys, L., Miller, E. Conceptualising convenience: Transportation practices and perceptions of inner-urban high density residents in Brisbane, Australia. Transport Policy, 2011, Vol. 18, Issue 1, pp. 289-297. https://doi.org/10.1016/j.tranpol.2010.08.012

36. Pizzato, G., Guimarães, L., Caten, C. The perception of pleasantness in a product of collective use : the bus shelter. Work, 2012, Vol. 41.Supplement 1, pp. 282-289 [cited 22.05.2018]. https://content.iospress.com/ download/work/wor0170?id=work\%2Fwor0170 https://doi.org/10.3233/ WOR-2012-0170-282

37. Ely, V. H. M. B., De Oliveira, J. M., Lodgsdon, L. A bus stop shelter evaluated from the user's perspective. Work, 2012, Vol. 41.Supplement 1, pp. 1226-1233. https://doi.org/10.3233/WOR-2012-0307-1226

38. Nabors, D., et al. Pedestrian road safety audit guidelines and prompt lists. Washington, DC, U.S. Dept. of Transportation, Federal Highway Administration, Office of Safety, 2007, 128 p.

39. Nikolopoulou, M., Kleissl, J., Linden, P.F., Lykoudis, S. Pedestrians' perception of environmental stimuli through field surveys: Focus on particulate pollution. Science of the total environment, 2011, Vol. 409, Issue 13, pp. 2493-2502. https://doi.org/10.1016/j.scitotenv.2011.02.002

40. Pereira, D.A.G., Faria, B.M.A., Goncalves, R.A.M., Carvalho, V.B.F. Prata, K.O., Saraiva, P.S., Navarro, T.P., Cunha-Filho, I. Relação entre força muscular e capacidade funcional em pacientes com doença arterial obstrutiva periférica: um estudo piloto. Jornal Vascular Brasileiro, 2011, Vol. 10, Issue 1, pp. 26-30 [online, cited 22.05.2018]. http://www.scielo. br/pdf/jvb/v10n1/v10n1a05.pdf

41. Iseki, H., Ringler A., Taylor B.D., Miller, M. and Smart, M. Evaluating Transit Stops and Stations from the Perspective of Transit Users, 2007 [online, cited 22.05.2018]. https://www.its.ucla.edu/wp-content/uploads/ sites/6/2014/06/Appendix-C.pdf

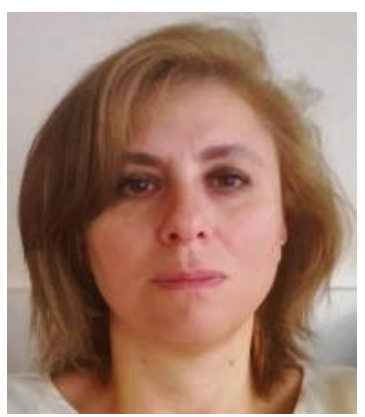

Gökçen Firdevs Yücel is Head of the Department of Industrial Design of Istanbul Aydin University. She received her BArch from Landscape Architecture Department of Istanbul University, and MSc in Landscape Planning Program from Istanbul Technical University. She earned her $\mathrm{PhD}$ degree in Landscape Planning Program from Istanbul Technical University. Her major research interests are landscape design, environmental perceptions and street furniture. She has been an associate editor of $\mathrm{A}+$ Arch Design journal of the Faculty of Architecture and Design of Istanbul Aydin University since 2015 . Dr. Yücel has published in her areas of expertise in proceedings of national and international congresses, national journals, and international book chapters.

Contact Data

Gökçen Firdevs Yücel

Faculty of Architecture and Design

Istanbul Aydin University

E-mail: gokcenfyucel@aydin.edu.tr 